\title{
Light, Temperature, and Sucrose Affect Color, Diameter, and Soluble Solids of Disks of Wax Apple Fruit Skin
}

\author{
Zen-hong Shü ${ }^{1}$, Cheng-chung $\mathrm{Chu}^{2}$, Lee-juan Hwang ${ }^{3}$, and \\ Ching-shung Shieh ${ }^{1}$ \\ Department of Plant Industry, National Pingtung University of Science and \\ Technology, Pingtung, Taiwan 912, Republic of China
}

Additional index words. tropical fruit, anthocyanin, interaction, Syzygium samarangense

\begin{abstract}
A study was conducted to assess the combined effects of light, temperature and sucrose on color, weight, diameter, and soluble solids of the skin of wax apple (Syzygium samarangense Merr. \& Perry) fruits. Skin disks were cultured in a factorial arrangement of two light levels [dark or light $\left(300 \mu \mathrm{mol} \cdot \mathrm{m}^{-2} \cdot \mathrm{s}^{-1}\right)$ ] as subplots and three sucrose concentrations $(0 \%, 3 \%$, or $6 \%)$ as sub-subplots within three temperature levels $(20,25$, or $30^{\circ} \mathrm{C}$ ) as whole plot treatments. Weight, diameter, soluble solids concentration (SSC), and anthocyanin content were measured 2 weeks after incubation. Light increased SSC and anthocyanin, but reduced the increase in weight and diameter. Increasing the temperature limited increase in diameter and anthocyanin content. Weight, SSC, and anthocyanin contents increased in a linear fashion with concentration of sucrose in the culture solution. However, none of the three factors played a unique role in anthocyanin synthesis in wax apple. Among the 18 combinations, light $/ 20^{\circ} \mathrm{C} / 6 \%$ sucrose gave the highest SSC and anthocyanin content, while dark $/ 20^{\circ} \mathrm{C} / 6 \%$ sucrose produced the largest diameter.
\end{abstract}

The wax apple belongs to the myrtle family (Myrtaceae) and is native to the Malay archipelago. In addition to the name wax apple, Java apple and wax jambu are commonly used English names. The wax apple, although almost completely unknown outside eastern Asia, is an economically important fruit crop in Taiwan (Shü et al., 1996; Wang, 1991). A mature wax apple tree is medium to large-sized, $\approx 5$ to $10 \mathrm{~m}$ tall, with a widely spreading and branched crown (Young, 1951). Flowers are fragrant, yellowish-white, $1 \mathrm{~cm}$ wide, and 4-petaled, with numerous stamens. The waxy fruit, light to dark red, sometimes green, greenish-white, or cream white-colored, is cone-shaped and narrow at the base with four fleshy calyx lobes at the apex, 5 to $6 \mathrm{~cm}$ long and 4 to $5 \mathrm{~cm}$ wide (Young, 1951). Wax apple fruit is usually eaten fresh (Nakasone and Paull, 1998).

'Pink' ('Nun-Young' in Chinese) is the leading cultivar, occupying $>99 \%$ of the planted area in Taiwan (Wang, 1991). The total area is 8000 ha (Taiwan Provincial Government, 1998), mostly concentrated in Pingtung prefecture. Although the tree blooms in March and April and the fruit ripens in May

\footnotetext{
Received for publication 8 Nov. 1999. Accepted for publication 11 July 2000. We thank Chung-ruey Yen for reviewing the manuscript and are grateful for the financial support from National Science Council of the Republic of China on Taiwan, grant No. NSC88-2313-B-020-004. The cost of publishing this paper was defrayed in part by the payment of page charges. Under postal regulations, this paper therefore must be hereby marked advertisement solely to indicate this fact.

'Professor.E-mail address:zhshu@mail.npust.edu.tw ${ }^{2}$ Research Assistant.

${ }^{3}$ Former Undergraduate Student.
}

cultured in a controlled environment. We tested factorial combinations of two light levels, three temperatures, and three sucrose levels to determine their effects on color, weight, diameter, and soluble solids of 'Pink' wax apple skin disks.

\section{Materials and Methods}

Plants. A wax apple orchard having 50 'Pink' trees in Yenpu, Pingtung, was used. Fruits $\approx 5 \mathrm{~cm}$ in diameter were harvested $50 \mathrm{~d}$ after flower shedding. The fruit were first washed with tap water and disinfected with $75 \%$ ethanol by wiping the whole fruit skin in a laminar flow hood. Skin disks $10 \mathrm{~mm}$ in diameter and $2 \mathrm{~mm}$ thick were taken from the calyx end of the fruit.

Methods. The diameter, weight, soluble solids concentration (SSC), and anthocyanin content of each fresh disk were measured immediately. Additional disks were disinfected with $75 \%$ ethanol for $60 \mathrm{~s}$ and washed twice with distilled water. Ten disks were placed on a paper bridge in culture vessels (Agripot; Takao, Kyoto, Japan), containing a $10-\mathrm{mL}$ $6 \%$ sucrose solution. The vessels were covered with caps [relative humidity (RH) $100 \%$ ] and placed in a growth chamber at a continuous $20^{\circ} \mathrm{C}$ in the dark for $36 \mathrm{~h}$. The disks were then transferred to similar vessels containing $0 \%, 3 \%$, or $6 \%$ sucrose, and were put into three growth chambers set at 20,25 , or $30^{\circ} \mathrm{C}$, with $12 \mathrm{~h}$ light/12 h dark. The light level was 300 $\mu \mathrm{mol} \cdot \mathrm{m}^{-2} \cdot \mathrm{s}^{-1}$ at the skin surface. Half of the vessels in each treatment were covered with black plastic bags. Samples were harvested $14 \mathrm{~d}$ later for measurement of diameter, weight, SSC, and anthocyanin contents. Soluble solids concentration in juice extracted from the skin was measured with a hand-held refractometer (Atago N-32, Tokyo). Anthocyanin is the primary red pigment for the red color in wax apple fruits (Shü, unpublished data). Singha et al. (1991) found a good correlation between anthocyanin concentration and chromaticity values. These relationships allow the use of a portable colorimeter for rapid, nondestructive estimation of fruit anthocyanin content in situ in apple. However, unlike the apple, the determination of red color in wax apple fruits was found to be more reliable when using anthocyanin content rather than chromaticity values (Shü, unpublished data). As a result, anthocyanin was determined spectrophotometrically in this study. Five skin disks $10 \mathrm{~mm}$ in diameter were put into $5 \mathrm{~mL}$ of $1 \% \mathrm{HCl}$ in methanol and incubated in the dark at $4{ }^{\circ} \mathrm{C}$. Optical density at $530 \mathrm{~nm}$ was measured $36 \mathrm{~h}$ later (Shü, 1999b).

Experimental design and statistical analysis. The experimental design was a split-splitplot with the three temperature levels as wholeplot treatments, the two light levels as subplots and the three sucrose levels as sub-subplot treatments. Each treatment combination (light/ temperature/sucrose) consisted of three replications. (Note that only one chamber was used per temperature, thus this factor technically was not replicated). The data were analyzed by SAS (SAS Institute, 1998). 


\section{Results}

The weight of skin disks of wax apple decreased significantly $(P \leq 0.001)$ following light treatment, but increased $(P \leq 0.001)$ when sucrose was added. Temperature did not affect disk weight. Interraction of light $\times$ sucrose or temperature $x$ sucrose or light $x$ temperature $\times$ sucrose were significant $(P \leq$ 0.01 to 0.001 ) in affecting disk weight, but light $\times$ temperature was not (Table 1). Disk diameter was influenced significantly $(P \leq$ 0.05 to 0.001 ) by light and temperature, either independently or in combination. The diameter of the cultured disks was greater in the dark than in the light. There was a negative linear relationship between temperature and diameter. Sucrose concentration did not significantly affect disk diameter. The widest and narrowest disk diameters were observed in the dark $/ 20^{\circ} \mathrm{C} / 6 \%$ and light $/ 30{ }^{\circ} \mathrm{C} / 6 \%$ treatments, respectively.

The soluble solids concentration was significantly $(P \leq 0.001)$ affected by light and sucrose alone and by interactions (Table 1), but not by temperature alone, the interaction of light $\times$ temperature, light $\times$ temperature $\times$ sucrose, or temperature $\times$ sucrose. Light significantly enhanced mean SSC $(7.0 \%$ in the light vs. $3.7 \%$ in the dark, Table 1). However, no significant difference in mean SSC was found among the three temperature treatments under either dark or light. With a value of $4.0 \%$ in fresh sample, the SSC in the treated skin disks ranged from $0.9 \%$ for light $/ 25^{\circ} \mathrm{C} /$ $0 \%$ and dark $/ 30{ }^{\circ} \mathrm{C} / 0 \%$ to $12.8 \%$ for light/ $20{ }^{\circ} \mathrm{C} / 6 \%$, and responded positively to sucrose concentration in the culture solution. Among the three combinations having high SSC values (light $/ 20{ }^{\circ} \mathrm{C} / 6 \%$, light $/ 25^{\circ} \mathrm{C} / 6 \%$, and light $/ 30^{\circ} \mathrm{C} / 6 \%$ ), the first was the best treatment by least square $t$ test. Anthocyanin content also ranged widely (from 0.007 for light $/ 30{ }^{\circ} \mathrm{C} / 6 \%$ to 1.644 for light $/ 20{ }^{\circ} \mathrm{C} / 6 \%$ ). All factors, either acting alone or in combination, had significant effects $(P \leq 0.05$ to 0.001$)$ on anthocyanin content, which was enhanced by light and sucrose concentration and reduced as temperature rose (Table 1).

\section{Discussion}

Color is probably the most important single factor among all quality factors, as external appearance is the parameter most used by the consumer in judging fruit quality of wax apples. Plants, when classified by anthocyanin synthesis, can be grouped into two categories: those that produce anthocyanin under the influence of light and those in which light is not required (Beggs and Wellmann, 1994). As our results show, the wax apple belongs to the first group. Skin disks placed in the dark stopped producing anthocyanin, whereas disks in the light continued to produce it (Table 1). Light is essential for red color development in apple (Saure, 1990) and light intensity, irradiation time (Creasy, 1968; Proctor and Creasy, 1971), and light quality, especially UV light (Chalmers and Faragher, 1977), influence anthocyanin pro-

Table 1. Effects of light (12 h), temperature, and sucrose on weight, diameter, SSC, and anthocyanin content in wax apple fruit skin following $14 \mathrm{~d}$ of treatment.

\begin{tabular}{|c|c|c|c|c|c|c|}
\hline $\begin{array}{l}\text { Light } \\
\text { treatment }^{2}\end{array}$ & $\begin{array}{l}\text { Temp } \\
\left({ }^{\circ} \mathrm{C}\right)\end{array}$ & $\begin{array}{c}\text { Sucrose } \\
\text { concn }(\%)\end{array}$ & $\begin{array}{c}\mathrm{Wt} \\
(\mathrm{mg})\end{array}$ & $\begin{array}{l}\text { Diam } \\
(\mathrm{mm})\end{array}$ & $\begin{array}{l}\text { SSC } \\
(\%)\end{array}$ & $\begin{array}{c}\text { Anthocyanin } \\
\text { (A530) }\end{array}$ \\
\hline Control (fresh sample) & 187 & 9.49 & 4.0 & 0.251 & & \\
\hline \multirow[t]{12}{*}{ Dark } & 20 & 0 & 138 & 9.55 & 1.6 & 0.214 \\
\hline & 20 & 3 & 185 & 9.87 & 3.6 & 0.390 \\
\hline & 20 & 6 & 188 & 10.02 & 5.7 & 0.706 \\
\hline & & Mean & $171 \mathrm{a}$ & $9.89 \mathrm{a}$ & $3.6 \mathrm{a}$ & $0.437 \mathrm{a}$ \\
\hline & 25 & 0 & 107 & 8.88 & 1.1 & 0.053 \\
\hline & 25 & 3 & 167 & 9.70 & 4.1 & 0.352 \\
\hline & 25 & 6 & 184 & 9.45 & 6.5 & 0.620 \\
\hline & & Mean & $152 \mathrm{ab}$ & $9.34 \mathrm{~b}$ & $3.9 \mathrm{a}$ & $0.342 \mathrm{a}$ \\
\hline & 30 & 0 & 167 & 9.32 & 0.9 & 0.048 \\
\hline & 30 & 3 & 150 & 9.33 & 2.9 & 0.072 \\
\hline & 30 & 6 & 130 & 9.20 & 6.7 & 0.106 \\
\hline & & Mean & $149 \mathrm{~b}$ & $9.28 \mathrm{c}$ & $3.5 \mathrm{a}$ & $0.075 \mathrm{~b}$ \\
\hline \multirow[t]{12}{*}{ Light } & 20 & 0 & 160 & 9.50 & 1.7 & 0.462 \\
\hline & 20 & 3 & 143 & 9.30 & 8.5 & 1.177 \\
\hline & 20 & 6 & 144 & 9.25 & 12.8 & 1.644 \\
\hline & & Mean & $149 \mathrm{a}$ & $9.35 \mathrm{a}$ & $7.7 \mathrm{a}$ & $1.094 \mathrm{a}$ \\
\hline & 25 & 0 & 120 & 8.93 & 0.9 & 0.035 \\
\hline & 25 & 3 & 144 & 9.66 & 7.6 & 0.574 \\
\hline & 25 & 6 & 159 & 9.81 & 11.4 & 1.222 \\
\hline & & Mean & $141 \mathrm{a}$ & $9.47 \mathrm{a}$ & $6.6 \mathrm{a}$ & $0.610 \mathrm{~b}$ \\
\hline & 30 & 0 & 147 & 9.20 & 1.1 & 0.017 \\
\hline & 30 & 3 & 143 & 8.85 & 7.0 & 0.024 \\
\hline & 30 & 6 & 127 & 8.35 & 12.3 & 0.007 \\
\hline & & Mean & $139 \mathrm{a}$ & $8.80 \mathrm{~b}$ & $6.8 \mathrm{a}$ & $0.016 \mathrm{c}$ \\
\hline \multicolumn{7}{|l|}{ Main effect means } \\
\hline Dark & & & $157 \mathrm{e}$ & $9.50 \mathrm{e}$ & $3.7 \mathrm{f}$ & $0.281 \mathrm{f}$ \\
\hline \multirow[t]{9}{*}{ Light } & & & $\begin{array}{l}143 \mathrm{f} \\
* * *\end{array}$ & $\begin{array}{c}9.21 \mathrm{f} \\
*\end{array}$ & $\begin{array}{l}7.0 \mathrm{e} \\
* * *\end{array}$ & $\begin{array}{c}0.581 \mathrm{e} \\
* * *\end{array}$ \\
\hline & 20 & & 160 & $9.62 \mathrm{~h}$ & 5.7 & $0.766 \mathrm{~h}$ \\
\hline & 25 & & 147 & $9.40 \mathrm{i}$ & 5.3 & $0.476 \mathrm{i}$ \\
\hline & 30 & & 144 & $9.04 \mathrm{j}$ & 5.2 & $0.066 \mathrm{j}$ \\
\hline & & & NS & $* * *$ & NS & $* * *$ \\
\hline & 0 & & $140 \mathrm{~m}$ & 9.23 & $1.2 \mathrm{n}$ & $0.154 \mathrm{n}$ \\
\hline & 3 & & 1551 & 9.45 & $5.6 \mathrm{~m}$ & $0.484 \mathrm{~m}$ \\
\hline & 6 & & 1551 & 9.38 & 9.21 & 0.8081 \\
\hline & & & $* * *$ & & $* * *$ & $* * *$ \\
\hline \multicolumn{7}{|l|}{ Interactions } \\
\hline Light $\times$ Temp & & & NS & $*$ & NS & $*$ \\
\hline Light $\times$ Sucrose & & & $* *$ & NS & $* * *$ & $* * *$ \\
\hline Temp. $\times$ Sucrose & & & $* *$ & $* * *$ & NS & $* * *$ \\
\hline Light $\times$ Temp. $\times$ Sucros & & & $* * *$ & NS & NS & $*$ \\
\hline
\end{tabular}

z $300 \mu \mathrm{mol} \cdot \mathrm{m}^{-2} \cdot \mathrm{s}^{-1}$

${ }^{y}$ Mean separation within sets (abc, ef, hij, lmn) by analysis of variance (ANOVA) and Duncan's multiple range test, $P \leq 0.05$.

Ns, *, *** Nonsignificant or significant at $P \leq 0.05$ or 0.001 by ANOVA.

duction. Anthocyanin formation in wax apple skin also responded to light (Table 1) and light intensity (Shü, unpublished data).

Like anthocyanin, SSC in skin also increased with irradiation. Light-treated disks had twice the amount of soluble solids as did fresh samples or disks kept in darkness. There are two possible mechanisms, passive and active, for sucrose uptake by the disks. In the present study, active uptake seems reasonable. First, the average SSC in the disk in the dark was roughly the same as the sucrose concentration in the culture solution in each treatment combination (Table 1). Second, the disks without added sucrose, both in the light and in the dark, had less SSC than the fresh sample, probably because of respiratory consumption. Third, the SSC of the disks treated with $3 \%$ or $6 \%$ sucrose in all combinations under the light was two to three times as great as that of the sucrose solutions in which they were in contact (Table 1). Apparently, light alone could not elevate the SSC of the disks in the absence of sugar. Without light, however, the SSC of the skin tissue could not exceed the concentrations provided. In other words, only passive uptake occurred in the dark.

Temperature is another important factor influencing anthocyanin synthesis. Anthocyanin synthesis is negatively correlated with temperature in apples (Creasy, 1968; Faragher, 1983) and marigold (Tagetes erecta L.; Armitage and Carlson, 1981). However, the effect of temperature on anthocyanin synthesis in apple is also influenced by the stage of fruit development (Faragher, 1983), cultivar, bagging or day/night temperature (Arakawa, 1991). Generally low temperature reduces respiration rate and carbohydrate consumption, thus enhancing anthocyanin synthesis (Creasy, 1968). Our results also show that low temperature favors anthocyanin synthesis and expansion in wax apple fruit skin disks (Table 1).

Sugar may serve as an energy source, osmotic regulator, or as a precursor for metabolic processes during plant development 
(Kuiper et al., 1991). It may also directly induce chalcone synthase gene expression (Tsukaya et al., 1991). The addition of sugar enhances anthocyanin synthesis in many crops, such as apples (Gianfagna and Berkowitz, 1986), grapes (Vitis vinifera L.; Pirie and Mullins, 1976), sorghum [Sorghum bicolor (L.) Merr.; Dube et al., 1992], and Impatiens balsamina L. (Klein and Hagen, 1961). Skin pigmentation of wax apple fruits is also markedly enhanced by sugars (Liao et al., 1999; Shü, 1999b). Among the four sugars tested, sucrose was the most effective in wax apple fruit (Liao et al., 1999). Sucrose also increased soluble amino acids, protein, SSC, total phenolic compounds, pigmentation and PAL activity (Shü, 1999b). In the present study, we demonstrated again that there were linear relationships between sugar and SSC as well as anthocyanin (Table 1). The relationships between sugar and weight and diameter were less clear. This may have been a result of the interactive effects exerted by light, temperature, and sugar used in this study.

We intended to find out which factor, among light, temperature and sugar, was most important in anthocyanin synthesis in wax apple fruits, so that special care could be taken in the management practices to maximize production of high quality fruit. However, no single factor appeared to play a unique role in anthocyanin synthesis. As a result, to ensure the production of high quality fruits, adequate amounts of light, temperature, and sugar (high fruit : leaf ratio) are required.

\section{Literature Cited}

Armitage, A.M. and W.H. Carlson. 1981. The effect of quantum flux density, day and night temperature and phosphorus and potassium status on anthocyanin and chlorophyll content in marigold leaves. J. Amer. Soc. Hort. Sci. 106:639-642.

Beggs, C.J. and E. Wellmann. 1994. Photocontrol of flavonoid biosynthesis, p. 733-751. In: R.E.
Kendrick and G.H.M. Kronenberg (eds.). Photomorphogenesis in plants, $2^{\text {nd }}$ ed. Kluwer Academic Publishers, The Netherlands.

Chalmers, D.J. and J.D. Faragher. 1977. Regulation of anthocyanin synthesis in apple skin. I. Comparison of the effects of cycloheximide, ultraviolet light, wounding and maturity. Austral. J. Plant Physiol. 4:111-121.

Cohen, E. 1988. The chemical composition and sensory flavour quality of 'Minneola' tangerines. I. Effects of fruit size and within-tree position. J. Hort. Sci. 63:175-178.

Creasy, L.L. 1968. The role of low temperature in anthocyanin synthesis in 'McIntosh' apple. Proc. Amer. Soc. Hort. Sci. 93:716-724.

Dann, I.R. and P.H. Jerie. 1988. Gradient in maturity and sugar levels of fruit within peach trees. J. Amer. Soc. Hort. Sci. 113:27-31.

Dube, A., S. Bharti, and M.M. Laloraya. 1992. Inhibition of anthocyanin synthesis by cobaltous ions in the first internode of Sorghum bicolor L. Moench. J. Expt. Bot. 43:13791382.

Faragher, J.D. 1983. Temperature regulation of anthocyanin accumulation in apple skin. J. Expt. Bot. 34:1291-1298.

Gianfagna, T.J. and G.A. Berkowitz. 1986. Glucose catabolism and anthocyanin production in apple fruit. Phytochemistry 25:607-609.

Klein, A.O. and C.W. Hagen, Jr. 1961. Anthocyanin production in detached petals of Impatiens balsamina L. Plant Physiol. 36:1-9.

Kuiper, D., H.S. van Reenen, and S.A. Ribot. 1991. Effect of gibberellic acid on sugar transport into petals of 'Madelon' rose flowers during bud opening. Acta Hort. 298:93-95.

Liao, S.C., Z.H. Shü, H.L. Lin, and K.C. Lee. 1999. Effects of sugars on anthocyanin biosynthesis in wax apple fruit skin (in Chinese). J. Agr. Assn. China, New Series 185:72-80.

Looney, N.E., R.L. Granger, C.L. Chu, L.N. Mander, and R.P. Pharis. 1992. Influences of gibberellins $\mathrm{A}_{4}, \mathrm{~A}_{4+7}$, and $\mathrm{A}_{4}+$ iso- $\mathrm{A}_{7}$ on apple fruit quality and tree productivity. II. Other effects on fruit quality and importance of fruit position within the tree canopy. J. Hort. Sci. 67:841-847.

Nakasone, H.Y. and R.E. Paull. 1998. Tropical fruits. CAB Intl., New York.

Pirie, A. and M.G. Mullins. 1976. Changes in antho- cyanin and phenolics content of grapevine leaf and fruit tissues treated with sucrose, nitrate, and abscisic acid. Plant Physiol. 58:468-472.

Proctor, J.T.A. and L.L. Creasy. 1971. Effect of supplementary light on anthocyanin synthesis in 'McIntosh' apple. J. Amer. Soc. Hort. Sci. 96:523-526.

Saure, M.C. 1990. External control of anthocyanin formation in apple. Scientia Hort. 42:181-218.

Shü, Z.H. 1999a. Position on the tree affects fruit quality of bald-cut wax apples. J. Appl. Hort. 1(1):15-18.

Shü, Z.H. 1999b. Total soluble solids, protein, phenylalanine ammonia-lyase activity and total phenol as related to anthocyanin biosynthesis in cultured wax apple fruit skin. J. Agr. Assn. China, New Series 185:102-110.

Shü, Z.H., D.N. Wang, and T.F. Sheen. 1996. Wax apple as a potential economic crop for the world, p. 69-73. In: S. Vijaysegaran; M. Pauziah, M.S. Mohamed, and S. Ahmad Tarmizi (eds.). Proc. Intl. Conf. Trop. Fruits. Vol. I. Malaysian Agr. Res. Dev. Inst., Serdang, Selangor, Malaysia.

Singha, S., T.A. Baugher, E.C. Townsend, and M.C. D'Souza. 1991. Anthocyanin distribution in 'Delicious' apples and the relationship between anthocyanin content and chromaticity values. J. Amer. Soc. Hort. Sci. 116:497-499.

Syvertsen, J.P. and L.G. Albrigo. 1980. Some effects of grapefruit tree canopy position on microclimate, water relations, fruit yield and juice quality. J. Amer. Soc. Hort. Sci. 105:454459.

Taiwan Provincial Government. 1998. Taiwan agricultural yearbook. Dept. Agr. For., Taiwan Prov. Govt., Nantou, Taiwan.

Tsukaya, H., T. Ohshima, S. Naito, M. Chino, and Y. Komeda. 1991. Sugar-dependant expression of the CHS-A gene for chalcone synthase from petunia in transgenic Arabidopsis. Plant Physiol. 97:1414-1421.

Wang, D.N. 1991. Past, present and future of wax apple production in Taiwan (in Chinese), $\mathrm{p}$. 339-355. In: C.R. Yang (ed.). Proc. Symp. Fruit Production, Research and Development in Taiwan. Chia-Yi Agr. Expt. Sta., Taiwan Agr. Res. Inst., Taiwan.

Young, J.F. 1951. Fruits in Taiwan (in Chinese). Chia-Yi Agr. Expt. Sta., Chia-Yi, Taiwan. 